\title{
School Performance and Leadership Styles Nexus: Exploring the Mediation Effect of Teacher Job Satisfaction in the Public Senior High Schools in Ghana
}

\author{
Cynthia Asamoah Gyimah \\ Department of Education, Texila American University Georgetown, Guyana, South America
}

\begin{abstract}
The increasing complexities of school settings and global educational reforms, school leadership has been recognized to play a key role in school performance worldwide. Nonetheless, the mechanisms through school leaders contribute to school performance has not been fully established till date especially due to difference in context of study, regional and cultural convolutions. To address this research lacuna, the study investigated the extent to which leadership styles directly and indirectly contribute teacher job satisfaction and school performance among selected Public Senior High Schools in the Kumasi Metropolis in Ghana. A sample size of 500 respondents were randomly selected and the Structural Equation Modelling (SEM) approach with Smart PLS software version 3.0 were employed for the analysis the data from the study. The study revealed that instructional, transactional, and the transformational leadership styles are the predominant leadership styles employed by the heads of the Public Senior High Schools in the study area. The instructional, transactional, and the transformational leadership styles have statistically significant and positive direct impacts on teachers' job satisfaction and school performance. Furthermore, teachers' job satisfaction only played statistically significant partial mediation effects in the relationship between transactional and transformation leadership styles and school performance. The study recommend that leadership in the senior high schools should put premium emphasis on the kind or leadership styles employed and teacher job satisfaction in their effort to improve school performance.
\end{abstract}

Keywords: Leadership styles, school performance, job satisfaction, Ghana

DOI: $10.7176 / \mathrm{JEP} / 11-15-12$

Publication date:May $31^{\text {st }} 2020$

\section{Introduction}

Improving school performance fundamentally take into account the school teachers, leaders, societies and resources in general. However, all these factors are largely influenced by leadership style and practice (Leithwood, 2006) and teachers' job satisfaction (Hosseinkhanzadeh, Hosseinkhanzadeh \& Yeganeh, 2013; Michaelowa, 2002; Somech, Drach-Zahavy \& Anat, 2000; Treputtharat \& Tayiam, 2014). The extent to which schools improve depend so much on the leadership styles employed by the head or leader of the school. Several studies have been conducted on the impact of educational leadership on academic performance at different levels of academic institutions. Among these studies include Lezotte and McKee (2006), Kouzes \& Posner (2012) and Leithwood, (2006,). Leadership styles and practice have been found to directly influence performance either positively or negatively. According to (Afful-Broni, 2005), school success also depends on the commitment level of all stakeholders of the school, which invariably affects the atmosphere for teachers and other staff to commit to their respective roles and performances.

Leadership is a concept that has been widely studied and researched across a variety of domains including both the business and educational worlds. Cezmi Savas and Toprak (2014) stated, "Leadership is known as an effort that directs organizational activities to achieve a common goal". With the ever-changing educational landscape, principals must incorporate a wide range of leadership skills and styles in order to direct their school organization towards common goals and a well-directed vision. The principal is the most influential person in a school. "The difference between more effective principals and their less effective colleagues is not what they know, it is what they do" (Whitaker, 2003). There have been numerous education reforms intended to raise the achievement standards of students for the past 30 years.

As a result of the complexity and constantly evolving school setting these reforms have created, school leadership becomes of great interest in international education as it is increasingly recognized as having a key role in improving student outcomes (Day, Gu \& Sammons, 2016; Mulford, 2008). Transformational leadership, transactional leadership and instructional leadership are the most regularly cited theories in education related literature (Robinson, 2008).

Transformational leadership focuses on establishing school culture and vision to enhance the quality of school teaching and learning, develop people, and improve the organization (Shatzer. 2014). While transformational leadership can strongly influence teachers, numerous studies (Leithwood \& Jantzi, 2006; Ross \& Gray, 2006) have concluded that these positive impacts have a much weaker effect on student achievement.

This model infers that a principals' efforts should be concentrated on the promotion of better outcomes for 
students, and the importance of improving the quality of classroom teaching and learning.Research on instructional leadership (Robinson, 2008, Shatze, 2014) has concluded that instructional leadership can influence student achievement, primarily through improvements to teacher's work conditions and school culture. These studies have concluded that it can have a more noticeable effect on student achievement than transformational and transactional leaderships, primarily because it places more of an emphasis on the quality of teachers and their teaching.

Transactional leaders identify primarily tasks of the followers, establish the structure, emphasis on planned and scheduled work. Followers are rewarded or punished to achieve organizational goals (Hoy \& Miskel, 2010). Ezeh (2008) observed that transactional leadership is more effective when organization desire to achieve their aims and objectives. Aydin, Sarier, and Uysal, (2013) show that transactional leadership affects job satisfaction at a broad level and in a positive way.

Extant literature has reported that leadership style and teachers' job satisfaction are closely related to school effectiveness including school performance (Ali, Sharma \& Zaman, 2017; Somech, Drach Zahavy \& Anat, 2000). It has also been shown that leadership style and school culture influences teachers' job satisfaction. Thus, leadership style, teachers' job satisfaction, and school performance can be assumed to be interrelated, though there is little known about the precise relationship among them especially in the context of Ghanaian education settings.

The extent to which schools improve depend so much on the leadership styles employed by the head or leader of the school. Several studies have been conducted on the impact of educational leadership on academic performance at different levels of academic institutions. Among these studies include Lezotte and McKee (2006), Kouzes \& Posner (2012) and Leithwood, (2006,). Leadership styles and practice have been found to directly influence performance either positively or negatively. According to (Afful-Broni, 2005), school success also depends on the commitment level of all stakeholders of the school, which invariably affects the atmosphere for teachers and other staff to commit to their respective roles and performances. Educational performance is the ultimate goal of educational policy makers and governments which serve as a key indicator to move economies. Some previous studies in Ghana such as Mensah, Okyere and Kuranchie (2013) and Boampong, Obeng-Denteh, Issaka and Anamuah-Mensah, (2016) have shown a falling standards of performance among the senior high schools especially in the case of mathematics yet among these studies, leadership styles of the heads of these institutions were found to be good. Therefore, several stakeholders have questioned the cause(s) of the falling standards of performance of the educational institutions especially the senior high schools in Ghana.

Based on this, this study ventured an argument in the following premises: Firstly, the study argued that even though leadership styles and practices of educational leaders and administrators impact on performance, the impact is mediated by job satisfaction of their subordinates. Secondly, the effect of leadership style employed by the educational leaders on school performance is also mediated by the teacher job satisfaction.

However, studies focused in this direction of these arguments is less explored particularly in Ghana among senior high school educational setting. Investigating the mediation role of school culture and job satisfaction in this study employed a novel statistical computation approach such as the structural equation Modelling (SEM) to conduct path analyses which is among the pioneering studies in Ghana to utilize this novel computational approach to study this kind of interactions. This study therefore aimed to narrow the existing gap and shortage of literature pertaining to heads leadership styles in relation to school culture, teachers' job satisfaction and school academic performance in Ghanaian Senior High School settings. Secondly, the findings can be used to help practicing administrators determine possible areas of focus for improving teacher effectiveness and student achievement.

These findings may be particularly relevant for practicing educational leaders in schools identified as low performing schools in need of improvement. Additionally, the findings of this study may be used by state educational leaders and policy making officials to assess current systems of evaluation for principals and other school level executives.

\section{Literature Review and Hypothesis Development}

Several studies demonstrated the relationship styles between school performance from different contexts, organizations, and methodology. In the educational settings, leadership styles such as the transactional, instructional and transformation are predominantly uses and have proved to be effective and support performance. In his view explains transactional leadership style as a form of leadership in which relationships with teachers are based upon an exchange for some valued resource. Through the transforming process, the motives of the leader and follower merge. Transformational leadership contributes positively to school performance. Educational leaders need not lead their institutions based on give-and-take relationships, but rather on the leader's personality or character traits, ability to cause change by being a leader's role model, as well as always committing to a shared vision and goals. It is incumbent upon the heads to emulate the kind of leadership style that will help them remain efficient in fulfilling their leadership obligations.

Nonetheless, Wangihti (2014 ) also believes that with regards to the leadership styles used by school principals the autocratic leadership style of school head was found to have a negatively influence on school teacher's levels of job performance. Again, the author articulate that Headmasters' laissez faire leadership style 
moderately influences school teacher's levels of job performance whilst transformational leadership style positively influences school teacher's levels of job performance as compared to transactional leadership style. It suggest that, headmasters need to mix more than one method of leadership style so that a positive atmosphere can be achieved.

Heaven and Bourne (2016) investigated on instructional leadership and its effect on students' academic performance in secondary educational institutions in Kingston and St. Andrew, Jamaica. The findings indicated that a positively weak statistical correlation existed between the performance of students and instructional leadership. Boampong, Obeng-Denteh, Issaka and Anamuah-Mensah (2016) studied the effect of leadership styles of head teachers on the academic performance of students in Ghana. The findings from these authors indicated that the leadership styles of head teachers have some influence on academic performance of students. Based on this background, the following hypothesis are developed:

H1a: Instructional leadership has significant positive impact on school performance

$\boldsymbol{H} 1 \boldsymbol{b}$ : transactional leadership has significant positive impact on school performance

H1c: transformational leadership has significant positive impact on school performance

Studies such as Krishnan, (2005) and Huang \& Chou, (2005) have demonstrated the significant relationship between leadership styles and employees' satisfaction in business organization. In this sense it is established that, the kind of leadership style exhibited in an organization determines the level of employee job satisfaction and their commitment towards the duty. As some leadership styles improve employee job satisfactions, others are seen to reduce job satisfaction of employees (Fernandes \& Awamleh, 2004; Rad \& Yarmohammadian, 2008; Lock \& Crawford, 2004; Griffith, 2004).

According to Rad and Yarmohammadian's (2008) leadership styles such as democratic, transformational and transaction contribute positively to employees' job satisfaction and suggested significant correlation between the employees' job satisfaction and the leadership styles of managers. Nonetheless, the study by Lok and Crawford (2004) found no significant differences with the impact of leadership styles on job satisfaction and commitment. According to Hungra, Chuni, Aslam, Azam and Rehman, (2005), there is a positive relationship between autonomy, leadership behavior, team work environment and job satisfaction.

Transformational leadership provides some indications on effective leadership practices that may contribute to teacher job satisfaction and work commitment. For example, one study by Griffith, (2004) suggests that transformational leadership, with its insights on instilling values and morals in an organization, had an indirect effect on job satisfaction and teachers' commitment to stay in the profession. The principal's leadership practices may influence job satisfaction and work commitment as a result of personal interactions to build the teacher's selfesteem, which is closely related to social identity, providing a sense of belonging to a group.

Specifically, it appears principals' effect on teachers' job satisfaction and work commitment may be mediated through collaborative relationships by providing teachers with professional recognition and appreciation of their work.

This is in agreement with Mees (2008) study of leadership behavior in public school leaders in relation to teacher job satisfaction in Cyprus. Evidently, perceived individual considerate behaviors of school principals satisfies an employee's needs and thus leading to the satisfaction of teachers on their job. Hence in this study, it is hypothesized that:

H2a: Instructional leadership styles has significant and positive impact on teacher job satisfaction.

$\boldsymbol{H} 2 \boldsymbol{b}$ : Transactional leadership styles has significant and positive impact on teacher job satisfaction.

H2c: Transformational leadership styles has significant and positive impact on teacher job satisfaction.

Job satisfaction plays a key role in the success of an organization's business, whereby the relationship between job satisfaction and performance has been shown to be significant (Usop, Kadtong \& Usop, 2013). And high employee job satisfaction is important in order for an organization to function and achieve its goals. In a similar manner, in an educational context the job satisfaction experienced by teachers is likewise crucial for schools' successful operation. Teacher Job satisfaction has been found to have a positive and significant effect on teaching efficacy (Collie, Shapka \& Perry, 2012), student learning (Michaelowa, 2002), student academic performance and school effectiveness (Somech et al., 2000).

For instance, Horn-Turpin (2009) investigated the job satisfaction levels of 121 teachers from special education and showed that this was positively correlated with their perceived teaching efficacy. Here, how satisfied the teachers were with their performance in the school, the more likely their practice was successful, and, therefore, the more likely the academic progress and achievement of their students met the educational targets (Treputtharat \&Tayiam, 2014). Liang, Chan, Lin and Huang (2011) take job satisfaction as mediator between transactional and transformational leadership style and articulate that these styles create strong correlation between employee's performances. In all, it has been shown that teacher job satisfaction appears to have a mediating role between school leadership and school effectiveness. Based on this, it is hypothesized that:

H3a: Teacher job satisfaction has positive and significant impact on school performance

H3b: Teacher job satisfaction mediate the relationship between Instructional leadership and school performance 
H3c: Teacher job satisfaction mediate the relationship between transactional leadership and school performance H3d: Teacher job satisfaction mediate the relationship between transformational leadership and school performance

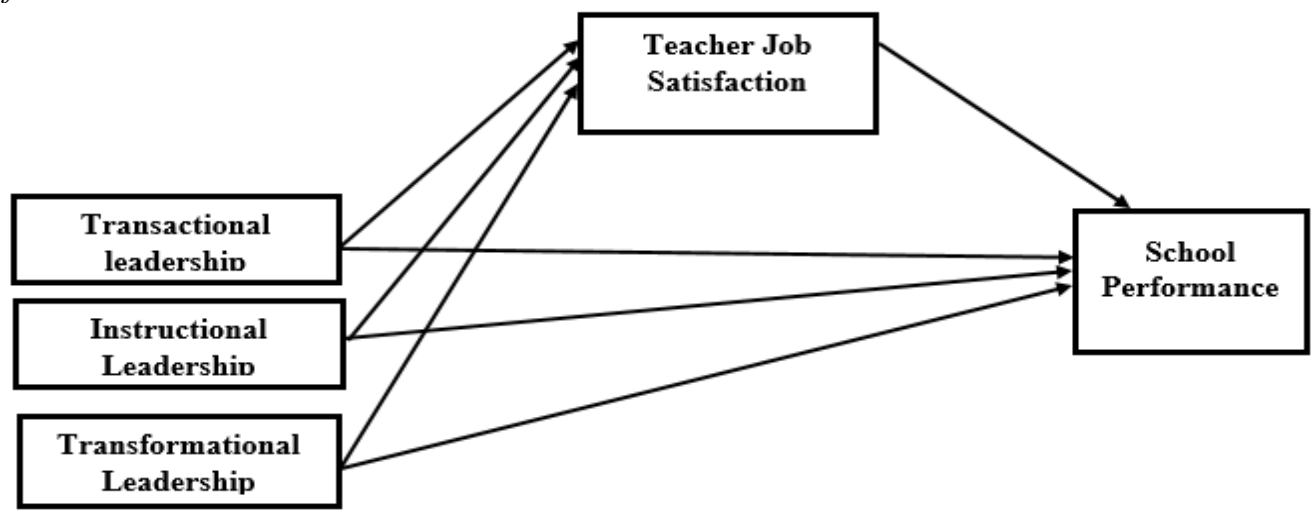

Based on the above literature review, the conceptual framework below was developed.

Figure 1: Conceptual Model for the study

\section{Methodology}

The paper investigated the extent to which leadership practices directly and indirectly influence job satisfaction and school performance in Public Senior High Schools in the Kumasi Metropolis in the Ashanti region of Ghana. Based on the objectives of the study, teacher job satisfaction variable served as the mechanism and the mediating variable through which the leadership styles influence school performance. In this study, the quantitative descriptive survey research design was employed to elicit adequate information to answer the research questions of the study. The study was conducted in Fifteen (15) different selected public Senior High schools in the Kumasi Metropolis in Ashanti Region in Ghana.

The Kumasi Metropolis capital city of the Ashanti Region in Ghana. The region is centrally located in the middle belt of Ghana and lies between longitudes $0.15 \mathrm{~W}$ and $2.25 \mathrm{~W}$, and latitudes $5.50 \mathrm{~N}$ and $7.46 \mathrm{~N}$. The region shares boundaries with four of the ten political regions including Brong-Ahafo in the north, Eastern region in the east, Central region in the south and Western region in the South west (GSS, 2012).

The study used the total sample size for the study was 500 respondent's Head masters, assistant Headmasters and teachers. The multi stage sampling method used were the stratified sampling, simple random sampling and the purposive sampling techniques. First, the researcher used proportionate stratified sampling technique. With this, the senior high schools in the Kumasi Metropolis were divided into four strata based on the type of school namely Category A, B, C and D. These categories are determined based on the development of infrastructures, resources and others factors which have the potential to affect school performance. Based on this, the researcher randomly selected five schools from Category A, four schools from Category B, three (3) schools from Category $\mathrm{C}$ while three schools were selected from Category D. Schools in the same category have similar features and characteristics. Moreover, since the respondents were Teachers in these senior High schools, the simple random sampling method was again used to select $25 \%$ of teachers from each of the schools selected.

In the final stage, the purposive sampling technique was then used to select the headmasters and their immediate assistant headmasters to be part of the respondents for the study. This constituted 15 headmasters and 15 assistant head masters. In all the total sample size of 500 respondents were selected and administered with questionnaires for the data collection.

The study used the structured questionnaires consisting of Likert scale type questions for the data collection from respondents. The Five-Point Likert Scale type responses were used for the study. The questionnaires were developed based on the conceptual framework of the studies, literature review, and the theoretical framework. This Likert scale type Reponses ranged from 1-Strongly Agree to 5- strongly Agree. The measuring instrument items were from the following sources. School Performance, Transactional leadership practices, Instructional leadership practices and Transformational leadership practices and teacher satisfaction (Hoy \& Miskel, 1996; De Nobile, 2007). The study employed the path analysis where latent variables were used for the study. Since the variables used for the study cannot be measured directly, a latent variables were used for the path analysis particularly to test the relationship between the variables using the observed variables. The study will utilize the partial least squares Structural Equation Modeling (PLS-SEM) for the analysis of the data. This method was used to examine various pathways and mechanisms through which the leadership practices influence school performance and teacher job satisfaction. . The use of structural equation modeling, the Smart PLS has been proven to be effective software for such analysis involving latent variables and mediation effect (Hair, Ringle \& Sarstedt, 2013). 


\section{Results and Discussion}

The study examined the extent to which Instructional leadership, transformational leadership, transactional leadership, influence school performance in the case of selected senior high schools in the Ashanti region in Ghana. In this study, Teacher job satisfaction served as mechanisms through which the leadership styles among the selected senior high schools influence the school performance. In this sense the structural equation model pathway analyses using Smart-PLS software was used in the study. The structural equation model approach help to simultaneously run multiple regression by exploring the direct and indirect effect of leadership styles through a mediation analysis. This section comprises the discussion of demographic characteristics of respondents, the evaluation of measurement model and evaluation of the structural model.

\section{Demographic Characteristics}

The respondents of the study constituted teachers, head of departments, headmasters, assistant headmasters in selected Public senior high school in the Kumasi Metropolis in Ghana. The results from the study indicated that, out of the five hundred (500) respondents who participated in the study, 386(77.2\%) were males while $114(22.8)$ were females. Respondents who took part in the study were predominantly males and this confirms the fact that, in the Kumasi Metropolis teachers in the Public senior high schools are predominantly males where their counterpart female teachers constitutes the minority.

In terms of age of respondents, the findings reveal that, participants below 30 years constitute 14.8\%, 30-40 years were $36.2 \%$, while 39.85 comprised those within $41-50$ years. The results show that. Only few of the respondents representing 9.2\% were within 51-60 years. This implies that, majority of the respondents were within 30-50 years. In the case of their highest educational attainment, the results show that, 412 of the respondents representing $82.4 \%$ had their first degree while 88 representing $17.6 \%$ had their post graduate degrees in different disciplines. This results confirm that the minimum qualification of the teachers in the public senior high schools in Ghana is the first degree.

Leadership styles practiced by headmasters of the selected senior high schools. In terms of working experience of the respondents, the results demonstrate that, $20.8 \%$ had working experience between 2-5years, whereas 32.4\% had 6-10 years of working experience. Similarly, the results show that, 24.85 had 11-15 years working experience while $22 \%$ had more than 15 years work experience. This shows that, most of the respondents had more than 5 years' work experience.

\section{Measurement Model}

The study examined the latent variables including Instructional leadership, transformational leadership, transactional leadership, school performance, teacher job satisfaction, and school culture. The purpose of the study was to investigate the extent to which leadership styles include school performance. Teacher job satisfaction served as mechanisms through which the leadership styles among the selected senior high schools influence the school performance. For a successful utilization of the PLS-SEM, the Confirmatory factor analyses were conducted. These latent variables were measured with observed construct items as shown in Table 1.

The confirmatory factor analyses were computed for the factor loadings of each observed construct indicator which combined to measure each of the latent variables. Results from Table 1 below presents the factors loading of the various observed measurement construct items, standard deviations, the variance inflation factors and the significant values measured as p-values. The results indicate that, all construct items had factors loadings greater than 0.7 which showed a good factor loadings form the confirmatory analyses. However, prior to these results, all the construct items with factor loadings less than 0.5 were dropped from the analyses since their loadings were not within the acceptable thresholds. The results present a minimal standard deviations which implies that, the responses were not widely dispersed and were closed to the average response to the selected construct items.

The P-values represent the significant level of the factor loadings for the observed construct indicators. The findings from Table 1 also present VIF values which did not exceed 10 and all the values were within the acceptable range of threshold. The Table 1.0 below indicated that, all the indicator items measuring the latent variable satisfied the requirement sufficient for the Structural equation model using Smart PLS-SEM bootstrapping 500 times (Hayduk \& Littvay, 2012). The table 1 below present the latent variables, observed construct items, VIF, factor loadings, standard deviation and significant level. 
Table 1: Confirmatory Factor Loadings

\begin{tabular}{|c|c|c|c|c|}
\hline Latent Variables & Observed construct indicators & VIF & $\begin{array}{l}\text { Factor } \\
\text { loadings }\end{array}$ & $\begin{array}{l}\text { Standard } \\
\text { Deviation }\end{array}$ \\
\hline $\begin{array}{l}\text { Instructional Leadership } \\
\leftarrow \text { INSTRUCT } 1\end{array}$ & $\begin{array}{l}\text { The leadership of this school monitors student } \\
\text { progress effectively }\end{array}$ & 1.544 & 0.763 & 0.039 \\
\hline $\begin{array}{l}\text { Instructional Leadership } \\
\leftarrow \text { INSTRUCT } 2\end{array}$ & $\begin{array}{l}\text { The leadership of this school discusses } \\
\text { instructional strategies with teachers }\end{array}$ & 2.059 & 0.892 & 0.014 \\
\hline $\begin{array}{l}\text { INSTRUCT } 3 \underset{\text { Instructional Leadership }}{\leftarrow}\end{array}$ & $\begin{array}{l}\text { The leadership of this school provides the } \\
\text { necessary resources to support teaching and } \\
\text { learning }\end{array}$ & 1.819 & 0.874 & 0.018 \\
\hline $\begin{array}{l}\text { PERFORM } 1 \leftarrow \text { School } \\
\text { Performance }\end{array}$ & $\begin{array}{l}\text { Compared to other school in the metropolis, } \\
\text { there has been improvement in enrollment in } \\
\text { this school for the past two years in the school }\end{array}$ & 3.141 & 0.905 & 0.013 \\
\hline $\begin{array}{l}\text { PERFORM } 2 \leftarrow \text { School } \\
\text { Performance }\end{array}$ & $\begin{array}{l}\text { There has been improvement in the academic } \\
\text { performance in this school for the past two } \\
\text { years compared with other schools in the } \\
\text { Metropolis }\end{array}$ & 2.951 & 0.896 & 0.013 \\
\hline $\begin{array}{l}\text { PERFORM } 3 \leftarrow \text { School } \\
\text { Performance }\end{array}$ & $\begin{array}{l}\text { There is low absenteeism rate among the } \\
\text { teachers in this schools compared with other } \\
\text { schools in the metropolis for the past two years }\end{array}$ & 1.415 & 0.78 & 0.027 \\
\hline $\begin{array}{l}\text { SAT } 1 \leftarrow \text { Teacher Job } \\
\text { Satisfaction }\end{array}$ & $\begin{array}{l}\text { Teachers' satisfaction with physical } \\
\text { surroundings in the school }\end{array}$ & 1.629 & 0.776 & 0.028 \\
\hline $\begin{array}{l}\text { SAT } 2 \leftarrow \text { Teacher Job } \\
\text { Satisfaction }\end{array}$ & $\begin{array}{l}\text { Teachers' satisfaction, with Teachers' } \\
\text { opportunities for teachers' promotion in the } \\
\text { school }\end{array}$ & 1.68 & 0.801 & 0.026 \\
\hline $\begin{array}{l}\text { SAT } 3 \leftarrow \text { Teacher Job } \\
\text { Satisfaction }\end{array}$ & $\begin{array}{l}\text { Teachers' satisfaction with Assistance for } \\
\text { teachers to improve work standards }\end{array}$ & 1.231 & 0.666 & 0.04 \\
\hline $\begin{array}{l}\text { SAT } 4 \leftarrow \text { Teacher Job } \\
\text { Satisfaction }\end{array}$ & $\begin{array}{l}\text { Teachers' satisfaction with resources to support } \\
\text { teachers to be creative and critical thinkers }\end{array}$ & 1.312 & 0.705 & 0.045 \\
\hline $\begin{array}{l}\text { TRANSACT1 } \leftarrow \text { Transactional Leadership } \\
\text { Tran }\end{array}$ & $\begin{array}{l}\text { The leadership of this school creates clear rules } \\
\text { and procedures and rewards teachers for } \\
\text { accomplished goals }\end{array}$ & 1.401 & 0.828 & 0.034 \\
\hline $\begin{array}{l}\text { TRANSACT } \underset{\text { Transactional Leadership }}{2} \\
\text { Trat }\end{array}$ & $\begin{array}{l}\text { The leadership of this school makes decisions } \\
\text { on their own without involvement of } \\
\text { subordinates and works to reduce resistance by } \\
\text { the staff to their decisions when they are } \\
\text { unfavorable }\end{array}$ & 2.137 & 0.859 & 0.028 \\
\hline $\begin{array}{l}\text { TRANSACT } \quad 3 \underset{\text { Transactional Leadership }}{\leftarrow}\end{array}$ & $\begin{array}{l}\text { The leadership of this school grants } \\
\text { subordinates autonomy without paying } \\
\text { attention to their quality of work, and only } \\
\text { intervenes after problems have occurred }\end{array}$ & 3.234 & 0.865 & 0.02 \\
\hline $\begin{array}{l}\text { TRANSFORM } \\
\leftarrow \text { Transformational } \\
\text { leadership }\end{array}$ & $\begin{array}{l}\text { The leadership of this school encourages } \\
\text { creativity and does not publicly criticize } \\
\text { mistakes }\end{array}$ & 3.069 & 0.7 & 0.038 \\
\hline $\begin{array}{l}\text { TRANSFORM } \\
\leftarrow \text { Transformational } \\
\text { leadership }\end{array}$ & $\begin{array}{l}\text { The leadership of this school shows that a } \\
\text { problem can be solved and everyone has a } \\
\text { voice in solving that problem }\end{array}$ & 1.169 & 0.842 & 0.022 \\
\hline $\begin{array}{l}\text { TRANSFORM } 3 \\
\text { Transformational } \\
\text { leadership }\end{array}$ & $\begin{array}{l}\text { The leadership of this school provides for staff } \\
\text { participation in the process of developing } \\
\text { school goals }\end{array}$ & 2.203 & 0.876 & 0.015 \\
\hline
\end{tabular}

The measurement model below demonstrate the individual observed constructs indicators measuring their latent variables. The estimated measurement model presented in figure 1 below presents the path ways through which the latent variables such as the leadership styles influence the school performance. The latent variables including school culture and teacher satisfaction serves as the mediating variables and the mechanisms through which the leadership styles play a role in school performance. The measurement model in figure 3 below also shows the factor loading, the R-square of the pathways model and the estimated coefficient of the direct pathways regression of the structural relationships among the variables. 


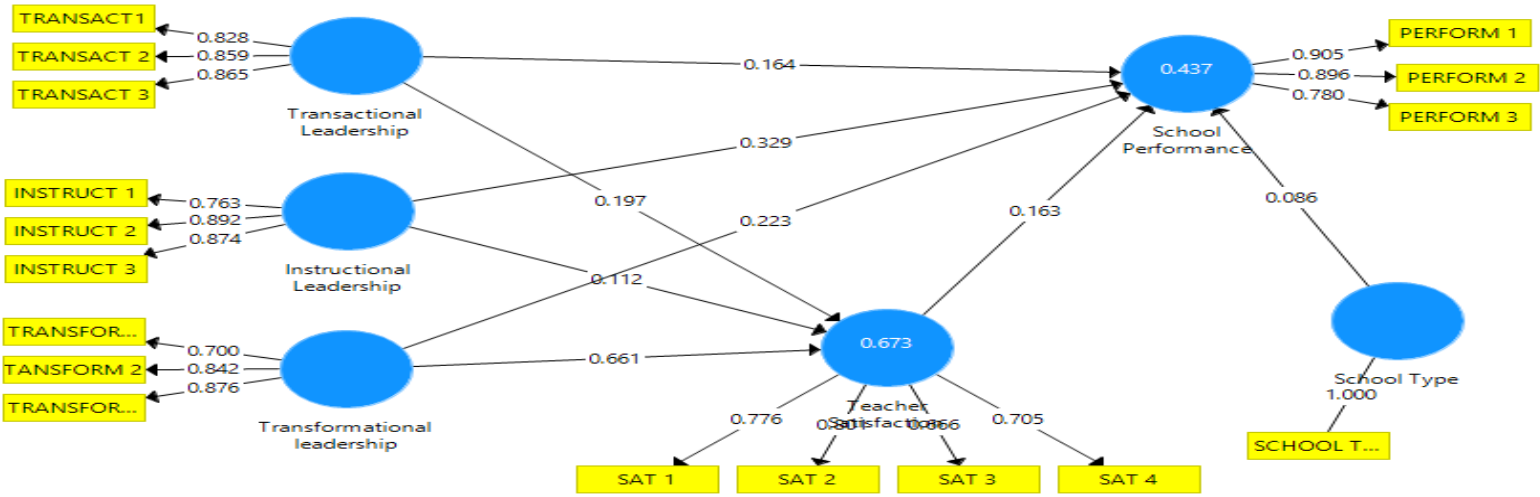

Figure 3: Measurement model

\section{Construct Reliability Tests}

In the analysis of the structural equation model, the validity and reliability of the measurement model of the measurement constructs were estimated. The composite Reliability (CR), average variance extracted (AVE), Cronbach's Alpha, and R-squared were computed as adequate measures of validity and reliability of the structural model and the results presented in Table 2. These measurements demonstrated the latent variable factors and indicators that were significantly consistent and reliable in measuring the structural model. The explanatory power of the model measured by R-square was also computed. According to (Hayduk and Littvay 2012) if the AVE and CR have loading less than 0.5 and 0.7 correspondingly, the results will imply weak convergence validity. As a results, are not desired to be maintained for the analysis.

The findings from the study show that the Cronbach's Alpha for all the latent variables used are above 0.7 which implies that, the latent variables are more reliable and consistent and appropriate for the structural equation modeling. Similarly, the Rho A, CR, and AVE for all the indicators are also above 0.7 which shows that, the items indicators were more reliable and valid for the analysis. The R-squared value which represent the explanatory power of the model revealed that, when school performance was used as the dependent variable, the R-square was 0.428 . This implies that, the model explains about $42.8 \%$ of the changes in the school performance are explained by the model. Simply when teacher satisfaction was used as dependent variable, the R-square was 0.670 which implies that about $67 \%$ of the changes in the teacher job satisfaction was explained by the model. The results are presented in the table 2 below.

Table 2: Results from Construct Reliability Tests

\begin{tabular}{|c|c|c|c|c|c|c|}
\hline Latent Variables & $\begin{array}{l}\text { Cronbach' } \\
\text { s Alpha }\end{array}$ & Rho_A & $\begin{array}{l}\text { Composite } \\
\text { Reliability }\end{array}$ & $\begin{array}{l}\text { Average Variance } \\
\text { Extracted (AVE) }\end{array}$ & $\begin{array}{l}\mathrm{R} \\
\text { Squar } \\
\mathrm{e}\end{array}$ & $\begin{array}{l}\mathrm{R} \\
\text { Squar } \\
\mathrm{e} \\
\text { Adjus } \\
\text { ted }\end{array}$ \\
\hline $\begin{array}{l}\text { Instructional } \\
\text { Leadership }\end{array}$ & 0.802 & 0.832 & 0.882 & 0.714 & \multirow{5}{*}{$\begin{array}{l}0.437 \\
0.673\end{array}$} & \multirow{5}{*}{$\begin{array}{l}0.428 \\
0.670\end{array}$} \\
\hline School Performance & 0.825 & 0.827 & 0.896 & 0.743 & & \\
\hline $\begin{array}{ll}\text { Teacher } & \text { Job } \\
\text { Satisfaction } & \end{array}$ & 0.720 & 0.724 & 0.827 & 0.546 & & \\
\hline $\begin{array}{l}\text { Transactional } \\
\text { Leadership }\end{array}$ & 0.825 & 0.914 & 0.887 & 0.724 & & \\
\hline $\begin{array}{l}\text { Transformational } \\
\text { leadership }\end{array}$ & 0.731 & 0.736 & 0.850 & 0.655 & & \\
\hline
\end{tabular}

\section{Discriminant validity test}

The results from the discriminant validity among these measured variables have been presented in Table 3 . The discriminant validity test was conducted using the Fornell-Larcker criterion to examine the extent to which the constructs differ from one another as shown in Table 3 below. The results from the Table 3 below presents the latent variables, numerical values in a major and minor diagonals. The values in the major diagonal represents the square root of AVE of the latent variable constructs while the values in off-diagonals are the cross-correlations between the constructs. The discriminant validity was then measured by comparing the differences between the overlapping constructs and the square root of the AVE. The findings below from demonstrate that, the difference between the cross correlations and the square root of the AVE are minimal and acceptable to justify for further analyses of the variables and their structural relationships. This consequently show that, the variables are valid 
and consistent to produce efficient outcome for the study. The results are presented in Table 3 below.

Table 3: Results from Discriminant validity Test

\begin{tabular}{llllll}
\hline Latent Variable & $\begin{array}{l}\text { Instructional } \\
\text { Leadership }\end{array}$ & $\begin{array}{l}\text { School } \\
\text { Performance }\end{array}$ & $\begin{array}{l}\text { Teacher } \\
\text { Satisfaction }\end{array}$ & $\begin{array}{l}\text { Transactional } \\
\text { Leadership }\end{array}$ & $\begin{array}{l}\text { Transformational } \\
\text { leadership }\end{array}$ \\
\hline $\begin{array}{l}\text { Instructional } \\
\text { Leadership }\end{array}$ & 0.845 & & & & \\
$\begin{array}{l}\text { School } \\
\begin{array}{l}\text { Performance } \\
\text { Teacher }\end{array}\end{array}$ & 0.493 & 0.862 & & & \\
$\begin{array}{l}\text { Satisfaction } \\
\text { Transactional }\end{array}$ & 0.416 & 0.553 & 0.739 & & \\
$\begin{array}{l}\text { Leadership } \\
\begin{array}{l}\text { Transformational } \\
\text { leadership }\end{array}\end{array}$ & 0.069 & 0.363 & 0.502 & 0.851 & \\
\hline
\end{tabular}

Pathway Analyses of Direct impacts of Leadership Styles and Teacher Job Satisfaction on School Performance.

To address the research objectives, the study examined the direct effect of leadership styles namely the instructional, transformational and transactional on school performance and teacher job satisfaction. Again, the direct effect of teacher job satisfaction on school performance was empirically examined. Results from Table 4 presents the presents the coefficient of direct pathways of the structural relationship between the leadership styles, teacher job satisfaction and school performance. The results reveal that, instructional leadership $(\beta=0.329, \mathrm{P}<0.01)$, transactional leadership $(\beta=0.164, \mathrm{P}<0.01)$, and transformational leadership $(\beta=0.223, \mathrm{P}<0.01)$ have statistically significant and positive impact on school performance. The findings imply that, headmasters of the senior high schools who employ predominately any of these leadership practice have the likelihood of improving school performance.

Nonetheless, among these leadership styles, the results demonstrate that, instructional leadership styles tend to have greatest direct impact on school performance compared to other leadership styles. Furthermore, the results show that, $(\beta=0.112, \mathrm{P}<0.05)$, transactional leadership $(\beta=0.197, \mathrm{P}<0.01)$, and transformational leadership $(\beta=0.661, P<0.01)$ have statistically significant and positive impact on teacher job satisfaction. The implication is that, the more school heads adopt these leadership styles the more likelihood that they would improve teacher job satisfaction in the senior high schools. More importantly, the results suggest that, transformational leadership $(\beta=0.661, P<0.01)$ tend to contribute greater improvement to teacher job satisfaction than other leadership styles considered in the study. These results are presented in the structural model in figure 3 below. The structural relationships presents the weights or the statistical significance of the relationships.

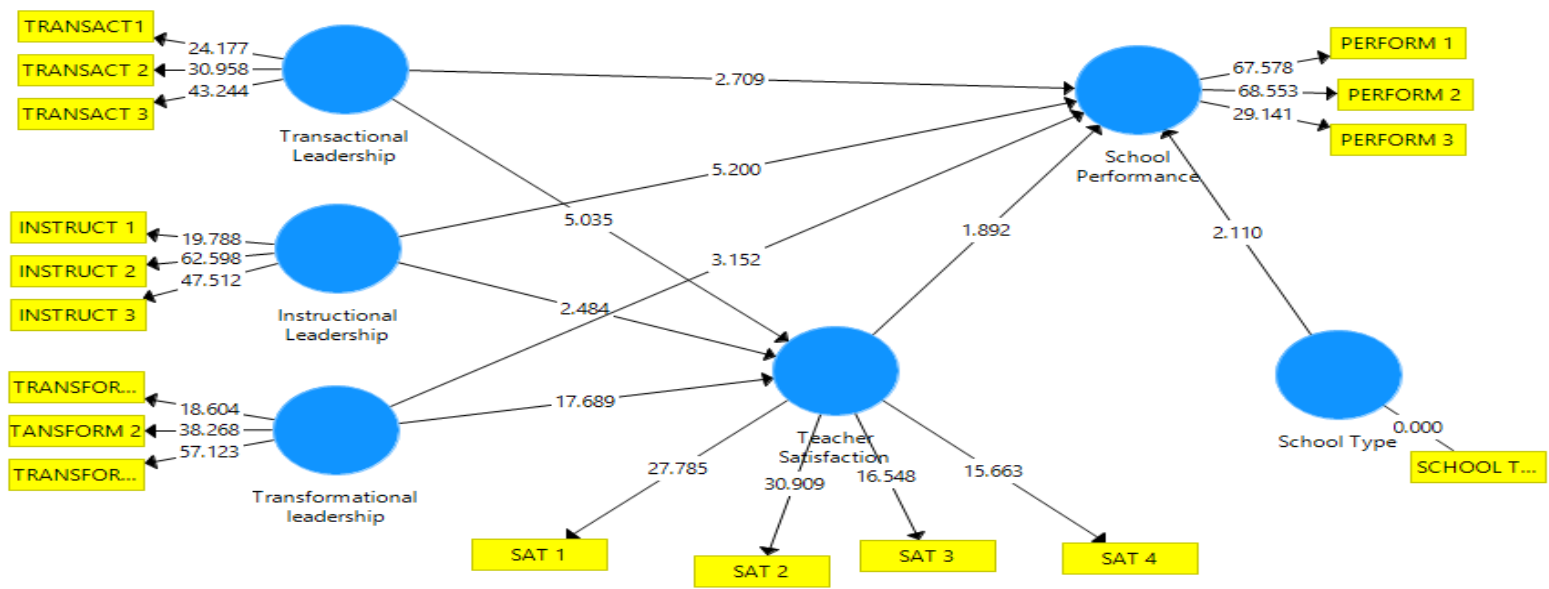

Figure 3: Structural Equation Model

Similarly, the results show that teacher job satisfaction $(\beta=0.163, \mathrm{P}<0.10)$ also have statistically significant positive and directly impact on school performance. Increasing teacher job satisfaction in the school contributes to increasing school performance. School type resented by category of school being category A, B, C and D was used in the model as a control variable. The results show that, type of school $(\beta=0.06, \mathrm{P}<0.05)$ has significant and positive impact of school performance. The results from the analyses are presented in table 4 below. 
Table 4: Direct Path coefficients

\begin{tabular}{lllll} 
Structural relationships & Coefficient & $\begin{array}{l}\text { Standard } \\
\text { Deviation }\end{array}$ & $\begin{array}{l}\text { T } \\
\text { Statistics }\end{array}$ & $\begin{array}{l}\text { P } \\
\text { Values }\end{array}$ \\
\hline Instructional Leadership $\rightarrow$ School Performance & $0.329^{* * *}$ & 0.063 & 5.200 & 0.000 \\
Instructional Leadership $\rightarrow$ Teacher Job Satisfaction & $0.112^{* *}$ & 0.045 & 2.484 & 0.013 \\
School Type $\rightarrow$ School Performance & $0.086^{* *}$ & 0.041 & 2.110 & 0.035 \\
Teacher Job Satisfaction $\rightarrow$ School Performance & $0.163^{*}$ & 0.086 & 1.892 & 0.059 \\
Transactional Leadership $\rightarrow$ School Performance & $0.164^{* * *}$ & 0.061 & 2.709 & 0.007 \\
Transactional Leadership $\rightarrow$ Teacher Job Satisfaction & $0.197^{* * *}$ & 0.039 & 5.035 & 0.000 \\
$\begin{array}{l}\text { Transformational leadership } \rightarrow \text { School Performance } \\
\text { Transformational leadership } \rightarrow \text { Teacher Job }\end{array}$ & $0.223^{* * *}$ & 0.071 & 3.152 & 0.002 \\
Satisfaction & $0.661^{* * *}$ & 0.037 & 17.689 & 0.000 \\
\hline
\end{tabular}

Note: $\rightarrow$ denote the direction of effect from the pathways analysis

Note: $* * * * * *$ denote $1 \%, 5 \%$ and $10 \%$ levels of significant level respectively

\section{Indirect Effect of Leadership Styles on School Performance}

The study further investigated the indirect effect of leadership styles practiced by the headmasters of the various senior high schools. In this direction, teacher job satisfaction serves as the mechanism through which leadership styles practiced in the schools affect school performance. The results from the mediation analysis presented in the table 4 below show that teachers job satisfaction significantly served as a partial mediation between transactional leadership $(\beta=0.032, \mathrm{P}<0.10)$ and school performance. This implies that, teacher job satisfaction serves as a partial medium through which transactional leadership practices affect school performance. This simply means that, transactional leadership can have both direct and indirect effect on school performance through teacher job satisfaction. In this case teacher job satisfaction becomes the partial pathways or channel through which transaction leadership style may affect school performance.

Likewise the results reveal that, teacher job satisfaction also have significant partial mediation effect in the relationship between transformational leadership style $(\beta=0.107, \mathrm{P}<0.10)$ and school performance. The results suggest that, even though transformational leadership can directly influence school performance, there is a more likelihood that, the channel of the effect can pass through teacher job satisfaction. However, the results reveal that, teacher job satisfaction does not have a significant mediation effect in the relationship between instructional leadership style and school performance. The results from the mediation analysis are presented in the Table 5 below.

Table 5: Indirect Path Coefficients

\begin{tabular}{lllll}
\hline Structural relationships & $\begin{array}{l}\text { Coeffici } \\
\text { ent }\end{array}$ & $\begin{array}{l}\text { Standard } \\
\text { Deviation }\end{array}$ & $\begin{array}{l}\text { T } \\
\text { Statistic } \\
\text { s }\end{array}$ & $\begin{array}{l}\text { P } \\
\text { Value } \\
\text { s }\end{array}$ \\
\hline $\begin{array}{l}\text { Instructional Leadership } \rightarrow \text { Teacher Job Satisfaction } \rightarrow \\
\begin{array}{l}\text { School Performance } \\
\text { Transactional Leadership } \rightarrow \text { Teacher Job Satisfaction }->\end{array}\end{array}$ & 0.018 & 0.013 & 1.422 & 0.156 \\
$\begin{array}{l}\text { School Performance } \\
\text { Transformational leadership } \rightarrow \text { Teacher Job Satisfaction } \rightarrow\end{array}$ & $0.107^{*}$ & 0.018 & 1.781 & 0.076 \\
School Performance & 0.057 & 1.876 & 0.061 \\
\hline
\end{tabular}

Note: $\rightarrow$ denotes the direction of effect from the pathways analysis

Note: $* * *, * * *$ denote $1 \%, 5 \%$ and $10 \%$ levels of significant significantly

\section{Discussion}

The study tested the various hypotheses of the structural relationships between the leadership styles, teacher job satisfaction and school performance. In all four key hypotheses with sub-constructs were tested. The results are presented in table 4 which demonstrated the hypotheses that were supported from the structural equation model analyses conducted. The results show that, the hypotheses $\mathrm{H} 1 \mathrm{a}, \mathrm{H} 1 \mathrm{~b}$ and $\mathrm{H} 1 \mathrm{c}$ were supported by the findings from the study. The hypothesis (H1a) which states that, instructional leadership style has positive and significant impact on school performance was supported. The findings from this study are agree with findings from (Robinson, 2008, Shatze, 2014) who conclude that instructional leadership can influence student achievement, primarily through improvements to teacher's work conditions and school culture. This as a results contributes significantly to improving school performance.

Likewise Hypothesis (H1b), which states that, transactional leadership style has positive and significant influence on school performance was supported.

In the same way, the findings show that, the hypothesis (H3a) which states that, transformational leadership style has positive and significant impact on school performance was supported. 
In the views of Day (2016) the concentration of leadership should be on promotion of better outcome, quality teaching and learning environment. Transformational and transactional leaderships, primarily focus on student achievement and quality teaching. The findings from this study justifies that, these leadership styles have positive effect on school performance including improvement in teaching and learning, improving infrastructure, maintaining disciplines among students and staff. All these translate to improve the overall school performance

Furthermore, the hypotheses $\mathrm{H} 2 \mathrm{a}, \mathrm{H} 2 \mathrm{~b}$ and H2c were also supported by the results from the study. Similarly, the hypothesis (H2a) which posit that, Instructional leadership style has significant positive impact on teacher job satisfaction was also supported by the results. Hypothesis $(\mathrm{H} 2 \mathrm{~b})$, which posits that, transactional leadership style has significant positive impact on teacher job satisfaction was also supported by the results.

Hypothesis (H2c), which posits that, transformational leadership style has significant positive impact on teacher job satisfaction was also supported by the results. The results from the study reveal that, good school leadership style has strong relationship with teacher job satisfaction. The findings show that, improving leadership styles such as instructional, transactional and transformational leadership styles contribute significantly to improving teachers' commitment, hardworking abilities and their entire job satisfaction in the school. The results of the hypothesis testing are presented in table 6 below.

Table 6: Results from hypotheses Tests

\begin{tabular}{|c|c|c|c|}
\hline Hypothesis test of Structural relationships & Coefficient & P Values & $\begin{array}{l}\text { Hypothesis supported } \\
\text { or not supported }\end{array}$ \\
\hline H1a: Instructional Leadership $\rightarrow$ School Performance & $0.329 * * *$ & 0.000 & Hypothesis supported \\
\hline H1b:Transactional Leadership $\rightarrow$ School Performance & $0.164 * * *$ & 0.007 & Hypothesis supported \\
\hline H1c:Transformational leadership $\rightarrow$ School Performance & $0.223 * * *$ & 0.002 & Hypothesis supported \\
\hline H2a: Instructional Leadership $\rightarrow$ Teacher Job Satisfaction & $0.112 * *$ & 0.013 & Hypothesis supported \\
\hline H2b:Transactional Leadership $\rightarrow$ Teacher job Satisfaction & $0.197 * * *$ & 0.000 & Hypothesis supported \\
\hline H2c:Transformational leadership $\rightarrow$ Teacher Satisfaction & $0.661 * * *$ & 0.000 & Hypothesis supported \\
\hline H3a:Teacher Job Satisfaction $\rightarrow$ School Performance & $0.163^{*}$ & 0.059 & Hypothesis supported \\
\hline $\begin{array}{l}\text { H3b: Instructional Leadership } \rightarrow \text { Teacher Job Satisfaction } \rightarrow \\
\text { School Performance }\end{array}$ & 0.018 & 0.156 & $\begin{array}{l}\text { Hypothesis not } \\
\text { supported }\end{array}$ \\
\hline $\begin{array}{l}\text { H3c: Transactional Leadership } \rightarrow \text { Teacher Job Satisfaction -> } \\
\text { School Performance }\end{array}$ & $0.032 *$ & 0.076 & Hypothesis supported \\
\hline $\begin{array}{l}\text { H3d: Transformational leadership } \rightarrow \text { Teacher Job Satisfaction } \rightarrow \\
\text { School Performance }\end{array}$ & $0.107 *$ & 0.061 & Hypothesis supported \\
\hline
\end{tabular}

Note: $\rightarrow$ denotes the direction of effect from the pathways analysis

Note: $* * * * *$ and $*$ denote $1 \%, 5 \%$ and $10 \%$ levels of significant respectively.

Moreover, the hypotheses $\mathrm{H} 3 \mathrm{a}, \mathrm{H} 3 \mathrm{~b}, \mathrm{H} 3 \mathrm{c}$ and $\mathrm{H} 3 \mathrm{~d}$ were also supported by the results from the study. Consequently, the hypothesis $(\mathrm{H} 3 \mathrm{a})$ which posits that teacher job satisfaction has significant and positive impact on school performance was supported. Again, the hypothesis $(\mathrm{H} 3 \mathrm{~b})$ which opine that teacher job satisfaction has a significant and positive mediation effect in the relationship between instructional leadership style and school performance was not supported.

In the same way, hypothesis ( $\mathrm{H} 3 \mathrm{c})$ which says that teacher job satisfaction has a significant and positive mediation effect in the relationship between transactional leadership style and school performance was supported. In the same way, hypothesis ( $\mathrm{H} 3 \mathrm{~b}$ ) which says that teacher job satisfaction has a significant and positive effect in the relationship between transformational leadership style and school performance.

Results from the mediation also demonstrate that, as teacher's satisfaction is increased, the resulting effect is improvement in school performance. The findings from the study and hypothesis testing conclude that teachers job satisfaction serves as a partial mediation through which leadership styles such as instructional, transactional and transformation contribute to school performance. This indicate that, the leadership styles practiced by the headmasters in the various senior high schools have both direct and indirect effect on school performance. To achieve the significant indirect effect of leadership on school performance, focus should be directed to improving teachers' job satisfaction in the school. The findings are also in line with Ali, Sharma and Zaman (2017) who found that leadership style and teachers' job satisfaction are closely related to school effectiveness including school performance. This implies that, for headmasters to achieve a meaningful; school performance teachers' job satisfaction should not be ignored. It must be part of the organization goals to be achieved especially by the school administrative board.

The findings also support the study by Afful-Broni, (2005), who argued that school success also depends on the commitment level of all stakeholders such as teachers of the school who contribute directly to the achievement and outcomes of the school activities particularly through teaching and learning activities. As concluded by Collie, Shapka \& Perry (2012) teacher Job satisfaction has been found to have a positive and significant effect on teaching efficacy student learning and school outcomes. 
Results from the study suggest that the kind of leadership styles employed in the senior high schools can significantly influence the quality of teaching, learning, student achievement and improvement in the overall school performance. The findings consequently demonstrate that student leadership styles utilized by the heads of the senior high schools can improve the working conditions of their teachers, teachers' job satisfaction. These findings are in line Shatzer, Caldarella, Hallam \& Brown, 2014) who argued that, good leadership has a noticeable impact on environment of their school which may result in their positive job satisfaction.

For example, Transformation school principals identify and share school vision, led and inspire others by example, create a culture of learning, and encourage staff members to undertake professional development. In the case of Instructional leadership, the emphasis is usually on the academic progress and achievement in the school. This indicates that, heads who employ this leadership styles to some extent achieve desired value of creating, clear educational goals, planning, curriculum objectives, and quality of teaching and learning performance.

\section{Conclusions and Recommendations}

The increasing complexities of school settings and global educational reforms, school leadership has been recognized to play a key role in school performance worldwide. Nonetheless, the mechanisms through school leaders contribute to school performance has not been fully established till date especially due to difference in context of study, regional and cultural convolutions. To address this research lacuna, the study investigated the extent to which leadership styles directly and indirectly contribute teacher job satisfaction and school performance among selected Public Senior High Schools in the Kumasi Metropolis in Ghana. Based conceptual framework of the study, teacher's job satisfaction served as the mechanism and a mediating variable through which leadership styles indirectly contribute to school performance. The study used a sample size of 500 respondents who constituted teachers, headmasters, and head of departments from 15 public senior high schools randomly selected from the Kumasi metropolis in Ghana. The structural equation model (SEM) approach was used to simultaneously examine the structural pathways through which school leadership styles and teachers job satisfaction influence school performance. The smart PLS software version 3.0 was employed for the analysis the data from the study.

Based on the analysis, the findings from the study revealed that instructional, transactional, and the transformational leadership styles are the predominant leadership styles employed by the heads of the public Senior High Schools in the study area. Results from the study show that, instructional, transactional, and the transformational leadership styles are have statistically significant and positive direct impact on teachers' job satisfaction. Nonetheless, the findings reveal that transformational leadership styles has the greatest influence on teacher job satisfaction among the senior high schools as compared to the other leadership styles.

Furthermore, the findings suggest that, instructional, transactional, and the transformational leadership styles had direct significant and positive impacts on school performance. Improvement in the use of these leadership styles contribute directly to significant increase in school performance. In terms of the extent of the impacts, the results demonstrate that, instructional leadership styles had the greatest direct significant positive impact on school performance while transactional had the least significant positive influence on school performance.

Moreover, the results show that, teachers' job satisfaction did not serve as full mediation in the relationship between the leadership styles and school performance. However, the findings subsequently reveal that, teacher job satisfaction played a partial mediation role in the structural relationships between leadership styles and school performance. This implies that, for heads of these public senior high schools to improve school performance, the job satisfaction of the teachers crucial and must not be ignored since the impact of the leadership practice could also pass through teacher job satisfaction. As the teachers become more satisfied, they are more committed, give out their best and contribute positively to school performance. In the other hand, if these teachers are not satisfied, their commitment levels may be low hence their contribution to school performance might be low.

In line with the above findings, the study recommend that, we recommend that, school administrators and heads especially in the senior high schools should employ more of transformational leadership styles. In exercising this kind of leadership, schools emphases on quality teaching and learning, developing human capital, and encourage staff to undertake professional development programs. Transformational leaders pay much attention to individual employee development, idealized influence, and intellectual stimulation. These are necessary to improve school performance which constitute academic achievement, improvement in school enrolment, discipline, reduction in staff absenteeism, school drop among others.

The findings from this study has a relevant contribution to practicing educational leaders in schools identified as low performing schools which need improvement in their performance. As the study identified the direct and indirect pathways through which leadership contributes to school performance, these findings are useful for school leaders to employ transformational leaders' styles, transaction in tandem with much emphasis on teacher job satisfaction in order to increase school performance. Additionally, the findings of this study may be used by state educational leaders and policy making officials to assess current systems of evaluation for principals and other school level executives. Findings from this study may provide additional validation for the inclusion of certain leadership practices, especially those related to teacher satisfaction, in the evaluation instrument of school level 
administrators.

Further, the study recommend that, leadership in the senior high schools should place much emphasis on improving teachers' job satisfaction. The findings revealed that, as teachers' job satisfaction is improved, they tend to show high level of commitment, dedication and unbridled zeal towards achieving the set goals in the school and high level of school performance. In conclusion, this study extend the empirical and conceptual evidence on the extent to which school leadership styles directly and indirectly contributes to school performance.

The study further suggest that, future studies may expand this study in terms of sample size and may employ other empirical analysis techniques such as hierarchical regression. In this direction, future research may consider other variable which may moderate the impact of leadership styles on school performance which constituted the limitation of this current study it considered only mediation variable. Examining the factors that moderate the relationship between leadership styles and school performance may strengthen the understanding of the current knowledge on the mechanism through which leadership styles influence school performance. Moderation variables such as resource allocation, government policies and school climate may be worthy of studying and included in the future model to study the nexus between school leadership and performance.

\section{References}

Afful-Broni, A. (2005). Theory and practice of educational leadership in Ghana. Accra:Yamens Press Ltd.

Ali, N., Sharma, S., \& Amir, Z. (2017). School culture and school effectiveness: secondary schools in Pakistan. Malaysian Online Journal of Educational Management, 4(4), 50-65.

Aydin, A., Sarier, Y., \& Uysal, S. (2013). The Effect of School Principals' Leadership Styles on Teachers' Organizational Commitment and Job Satisfaction. Educational Sciences: Theory \& Practice, 13(2), 806-811.

Boampong, S., Obeng-Denteh, W., Issaka I., \& Anamuah-Mensah, A. P. (2016). The Effects of Leadership Styles of Head Teachers on Academic Performance at Seniagya - Effiduase Sekyere East in the Ashanti Region. British Journal of Education, Society \& Behavioural Science, 17(3), 1-12.

Cezmi Savas, A., \& Toprak, M. (2014). Mediation efect of schools' psychological climate on the relationship between principals' leadership style and organizational commitment. Anthropologist, 17(1), 173-182.

Collie, R. J., Shapka, J. D., \& Perry, N. E. (2012). School climate and social-emotional learning: Predicting teacher stress, job satisfaction, and teaching efficacy. Journal of educational psychology, 104(4), 1189.

Day, C., Gu, Q., \& Sammons, P. (2016). The impact of leadership on student outcomes: How successful school leaders use transformational and instructional strategies to make a difference. Educational Administration Quarterly, 52, 221-258.

Ezeh, L. (2008). Influence of gender and leadership style on career commitment and job performance of subordinates. Global Journal of Humanities, 7(1), 1-8.

Fernandes, C., \& Awamleh, R. (2004). The impact of transformational and transactional leadership styles on employee's satisfaction and performance: An empirical test in a multicultural environment. International Business \& Economics Research Journal, 3(8), 65-76.

Ghana statistical service (2010). Population and housing census in Ghana.

Griffith, J. (2004). Relation of principal transformational leadership to school staff job satisfaction, staff turnover, and school performance, Journal of Educational Administration, 42(3), 333 - 356.

Hair, Joseph F, Christian M Ringle, and Marko Sarstedt. 2013. "Partial least squares structural equation modeling: Rigorous applications, better results and higher acceptance." Long range planning no. 46 (1-2):1-12.

Heaven, G., \& Bourne, P. A. (2016). Instructional Leadership and Its Effect on Students' Academic Performance. Review Pub Administration Manag, 4(3), 197.

Horn-Turpin, F. D. (2009). A study examining the effects of transformational leadership behaviors on the factors of teaching efficacy, job satisfaction and organizational commitment as perceived by special education teachers. Doctoral dissertation. Virginia Polytechnic Institute and State University.

Hosseinkhanzadeh, A. A., Hosseinkhanzadeh, A. \& Yeganeh, T. (2013). Investigate relationship between job satisfaction and organizational culture among teachers. Procedia-Social and Behavioral Sciences, 84, 832836.

Hoy, W. K., \& Miskel, C. G. (2008). Educational administration: Theory, research and practice. ( $8^{\text {th }}$ edn.). McGraw-Hill, Boston.

Huang, M., Cheng, B., \& Chou, L. (2005). Fitting in organizational values: The mediating role of person organization fit between CEO charismatic leadership and employee outcomes. International Journal of Manpower, 26(1), 35-49.

Kouzes, J. M., \& Posner, B. Z. (2003). The leadership challenge (3rd ed.). San Francisco, CA: Jossey-Bass.

Krishnan, V.R. (2005a). Leader-member exchange, transformational leadership, and value system. Electronic Journal of Business Ethics and Organization Studies, 10(1), 14- 21.

Leithwood, K., Day, C., Sammons, P., Harris, A., \& Hopkins, D. (2006). Seven strong claims about successful school leadership. National College for School Leadership. 
Leithwood, K., Jantzi, D. (2006). Principal and teacher leadership effects: A replication. School Leadership and Management, 20, 415-434

Lok, P. and Crawford, J. (2004). The effect of organizational culture and leadership style on job satisfaction and organizational commitment - A cross-national comparison. Journal of Management Development, 23(4), 321-338

Mees, G. E. (2008). The relationships among principal leadership, school culture and student achievement in Missouri Middle Schools. A University of Missouri-Columbia Phd Dissertation. Retrieved from: http://www.nassp.org/portals/0/content/59554.pdf

Mensah, J. K., Okyere M. \& Kuranchie, A. (2013). Student attitude towards mathematics and performance: Does the teacher attitude matter. Journal of Education and Practice, 4(3), 132-139.

Michaelowa, K. (2002).. Teacher job satisfaction, student achievement, and the cost of primary education in Francophone Sub-Saharan Africa (No. 188). HWWA Discussion Paper.

Mulford, B. (2008) The Leadership Challenge: Improving Learning in Schools. http://research.acer.edu.au/cgi/viewcontent.cgi?article=1000\&context=aer

Rad, A., \& Yarmohammadian, M. (2008). A study of relationship between managers' leadership style and employee's job satisfaction. Leadership in Health Services, 19(2), 11-28

Robinson, V. M. J., Lloyd, C. A., \& Rowe, K. J. (2008). The impact of leadership on school outcomes: An analysis of the differential effects of leadership types. Educational Administration Quarterly, 44(5), 635-674.

Ross, J.A. and Gray, P. (2006) Transformational Leadership and Teacher Commitment to Organizational Values: The Mediating Effects of Collective Teacher Efficacy. School Effectiveness and School Improvement, 17, 179-199.

Shatzer, R. H., Caldarella, P., Hallam, P. R., \& Brown, B. L. (2014). Comparing the Effects of Instructional and Transformational Leadership on Student Achievement: Implications for Practice. Educational Management Administration \& Leadership, 42, 445-459.

Somech, A., \& Drach-Zahavy, A. (2000). Understanding extra-role behavior in schools: The relationships between job satisfactions, sense of efficacy, and teachers' extra- role behavior. Teaching and Teacher Education, 16(5), 649-659

Treputtharat, S. \& Tayiam, S. (2014). School climate affecting job satisfaction of teachers in primary education, Khon Kaen, Thailand. Procedia-Social and Behavioral Sciences, 116, 996-1000.

Usop, A. M., Kadtong, M. L. \& Usop, D. A. S. O. (2013). The significant relationship between work performance and job satisfaction in Philippines. International Journal of Human Resource Management and Research, $3(2), 9-16$.

Wangithi, G. J. (2014). Influence of head teachers' leadership styles on teachers' job satisfaction in public primary school in Kajiado North District, Kajiado County, Kenya. Unpublished.

Whitaker, K. (2003). Principal role changes and influence on principal recruitment and selection: An international perspective. Journal of Educational Administration, 41(1), 37-54. 